\title{
ASSESSING JOB PREFERENCES OF MEDIA AND COMMUNICATION STUDENTS IN THE COVID ERA: A CONJOINT ANALYSIS
}

\author{
Vartika Kapoor \\ Research Scholar, Amity University, Noida \\ Dr Jaya Yadav \\ Professor, Amity University, Noida
}

\begin{abstract}
The purpose of this paper is to explore job attribute preferences of students in the media and communication stream. The study is conducted to get an understanding of job expectations of students in the COVID era that can help provide conceptual guidelines to hiring managers in media houses for future planning of manpower/job offers. Based on the conjoint analysis technique, a questionnaire was designed and responses of 152 students of media and communication were recorded from a university in Delhi/NCR. Estimation of preference function was created using orthogonal arrays. Results of this study suggest that job security is the most preferred attribute which influences job choice decisions of students, second preferred attribute being appropriate work hours. The paper presents an important tool that can be of great use for recruitment managers, to understand the psyche of students and their preferences, which may further help in designing appropriate recruitment policies and create job offers that can attract the suitable talent pool. Results also reveal that high compensation package is not the most preferred attribute anymore, perhaps due to the uncertainty of the times. Limitation of this study is that individual behaviour cannot be ascertained through the survey and data from students of different universities can be studied for more robust results. The paper is novel in approach as it empirically identifies the preferred job attributes of media students amid the pandemic situation, by applying conjoint analysis. Therefore, it gives new insights to understand how the pandemic has affected students' job expectation and decisions.
\end{abstract}

Keywords: Job Attributes, Conjoint Analysis, Students' Job Preferences, Media and Communication

\section{INTRODUCTION}

The year 2020 has taught us a great lesson on uncertainty and has been quite harsh on students, their career aspirations are at a standstill, with all educational institutes being shut and campus placements halted. Media industry is going through a tough time, with numerous controversies against certain media houses, journalists and reporters, police cases etc. There is all round negativity and such news on TV and other media can cause emotional burn out and stress among students (Havrylets et al., 2019) about the nature of job profiles. Thus, job attributes that attracted the students earlier may not be relevant now. During these difficult times when the world economy has taken a dip, several psychological changes have taken place among individuals. It is to be taken into account that organizational reputation has taken a backseat and students seek job security because it has an important role in emotional well-being ,quality of work-life; also, individuals worry less about their future which in turn, improves productivity and satisfaction at work (Sanyal et al., 2018).

Extent of job insecurity has great impact on job performance (Debus, 2020). FOMO is a known word in media studies, but it affects not only investment decisions (Shiva et al., 2020) but career FOMO affects job choices to a greater extent. These days, students are more inclined towards social media activism (De Moraes et al., 2020) and information exchange on social media about job situation, news of layoffs across the globe etc. has created fear in the minds of students making them anxious about their careers. Dhoot (2020) suggests that effective communication via media sources may help individuals in planning their future ahead.

Students who expected higher pay packages (Karima et al., 2020 ) are now ready for lower packages, but want to have a source of income desperately. Therefore, it becomes important 
for recruitment managers to prepare themselves for the upcoming revival and hiring thereafter. This study will help hiring managers in deciding hiring process, job design, planning compensation and benefits, and other human resource practices. There have been various studies that focussed on job attributes, such as Sutherland (2011), who concluded that work environment, job security and job profile are preferred more by employees. Other studies such as Corrigall \& Konrad (2006); Konrad (2003); Tolbert \& Moen (1998); Browne (1997), revealed that gender difference plays a key role in job profile preferences. Konrad (2003) noted that preferences are not constant and change with changes in financial, social and emotional needs.

A study done by Ng.et al. (2010) suggested that salary, work hours, job profile and work environment are the attributes preferred by millennials. Since the number and nature of job attributes are not consistent across researches (Guillot-Soulez \& Soulez, 2014), we cannot generalize the attributes. Management must understand job aspirations of an applicant from the organization. One way could be to design the job offer based on its appeal to top talents in the organization (Barney \& Wright, 1998). A sound knowledge of preferences can guide the organization in tailoring the best possible hiring strategy (Rynes \& Barber, 1990).

Studies done with the same job attributes had been done during normal times and hence present the results or preferences at that time. COVID has completely changed job scenario across the globe. To the best of our knowledge, no study has been done using conjoint technique on job preferences of media students amid the pandemic situation. Therefore, assessment of how the pandemic has affected job preferences of students using conjoint technique offers a new approach to human resource and media studies. Objectives of this study are - (a) to identify and assessing the job attribute preferences of students of Media and Communication in north India; (b) measure the utility of the attributes at each level and studying their relative importance.

\section{LITERATURE REVIEW}

Job attributes can be explained as the different facets of a job that satiates the emotional, social and financial requirements of an individual such as work self-efficacy and confidence (Pinder, 1998). It is all about aspects of a job that attract an individual to it (Konrad, Ritchie, Lieb, \& Corrigall, 2000). Attributes and levels have been discussed below:

\section{Salary}

McCaleb, Shaw, and Denny (1980) concluded, that monetary incentives are of greatest value, non-monetary benefits cannot match the money driven motivation. Organizations need to carefully design the structure of compensation and benefits, which is very crucial for attracting the right type of talent pool. Attractive pay package also contributes in improved employee commitment and loyalty (Llanos \& Ahmad, 2017). Good pay package has a deep positive impact on employee psychology, with lower turnover intentions (Tran 2016), and enhances motivation (Ferreira \& Badya, 2016). It also improves productivity of employees (Yamoah, 2013). (Perrin 2003), surveyed thirty five thousand employees in the US, suggested that preference for compensation may vary as per the objective of an individual; competitive base pay ranked second. Smola \& Sutton (2002) did a comparative study on work values of Gen X and Gen Y millennials and concluded that they differ significantly from each other, Gen $Y$ having high salary expectations, flexible work hours, unlike Gen $X$. Other studies also support the importance of salary as a job attribute for Gen Y (Meier et al., 2010).

\section{Working hours}

Covid induced economic shock is likely to realign the perception of the corporate world creating a shift in work cultures at micro and macro levels (Kramer \& Kramer, 2020). (Grantham et al. 2009) explained that flexible work hours have various dimensions - first, employees can start and end the day at their own convenience, but specific number of hours need to be put in every day, or it can be a weekly arrangement where work hours are assessed on weekly basis, not per day. This type of arrangement helps employees to have control over their schedule. (Rocereto et al., 2011). Recent studies have noted that millennials prefer flexible work hours (Deloitte 2018), and researchers point out that in future, flexible work hours will be a norm 
except in a few sectors (Chung \& Lippe, 2020). Flexi working gives control of time and place of work to the individual, which they can manage as required (Kelly et al., 2011, Chun et al. ,2018) and it also helps in managing workfamily conflicts (Kelly et al., 2014). Another dimension that is an important aspect of flexi schedule is remote working. COVID era has made employees work remotely and organizations as well as employees have now adapted quite well to the virtual workplace concept. It also helps in learning the knowledge sharing concept; a recent study suggested that knowledge sharing behaviour in virtual communities has improved (Fauzi et al., 2020).

Some studies also suggest that preference for normal or flexible workhours depends on family situations as well (Lippe et al., 2010); some employees may have more dependants and therefore more responsibilities to manage, hence they prefer flexible work hours; some may prefer normal timings as they do not have much responsibility at home. On the other hand, some researchers pointed out mixed results for flexible working hours, since it creates more conflict at home due to blurring of work boundaries, requires multitasking and may create more fatigue (Demerouti et al., 2014).

\section{Organizational Reputation}

Organizational reputation can be described as the collective perception about prominence of a firm (Zavyalova, Pfarrer \& Reger, 2016; Jehn \& Scott, 2015). There have been numerous empirical pieces of research on the basis of different theories of organizational or corporate reputation, but they have been used in management with different perspectives (Ali et al. 2014; Dowling 2016). Researchers suggested that organizational reputation is about perception, therefore it is simple yet complex to understand (Lange et al., 2011, p. 154). Job offer consists of job features and about employment policies. Reputation of an organization provides credibility to the job features and benefits mention in a job offer; therefore, job seeker perceives such organizations as more promising with lesser uncertainty.

Thus, a high reputation attracts more talent and low repute discourages talent. In today's era of uncertainty, job seekers look for credibility and that is why organizational reputation plays a big role in the war for talent (Micheal et al., 2001). Fombrun \& Shanley (1990); Belt \& Paolillo (1982) pointed out that corporate reputation is a very important element of job choice decisions. This study does not consider the job seekers' perception about various organizations, but how important this attribute is while making job choice decisions.

\section{Job Security}

Borland (1999) explained job security as not fearful of job loss. It is all about the assurance or confidence that the job is safe and the employee is going to stay for long. Hsiao and Nova (2016) also stated that workenvironment, job security and growth perspectives affect job decisions. Nurfitraih et. al. (2019) studied factors that impact job choice decisions and found that attributes such as salary, and job security were strongly correlated with career decision making. Aucejo et. al (2020) surveyed around 1500 students and found that almost $40 \%$ lost a job or job offer, therefore this pandemic has affected their expectation about job prospects post college. Ralph Heibutzki (2013) suggested in in a Forbes article that job security is an important dimension for employees as it touches upon their basic career expectations such as stability in career is equivalent to stability in life; it enhances motivation and confidence towards life situations; and, it provides stability to the curriculum vitae and hence makes good foundation for the next job. Thus, job security has great importance in job choice decisions.

Hsiao and Nova (2016) also noted that job security, good pay and work environment affect job choice decision making. Job security provides credibility to continuing employment and reduces fears about future unemployment in uncertain times (Lucky et al., 2013: 65); therefore, absence of threatening factors (Jandaghi et al., 2011: 6854) may affect employees' well-being.

\section{RESEARCH METHOD}

In this paper we considered job offers as a service product to be sold to potential candidates by the hiring managers and job profile/attribute are features that employee will earn in return of their services to the organization. While accepting the offer, they 
need to invest in terms of time, labor, and services to the organization. Such type of conceptualization encourages researchers to use marketing tools. Conjoint analysis is mainly used for designing a product or for designing a job offer (Wilcox, 2008; Kreiger et al., 2001).

\section{Conjoint Analysis}

Conjoint analysis was first introduced by Green \& Rao (1971) in marketing literature. Green \& Srinivasan (1978) asserted that conjoint analysis has a decomposition approach for analyzing the preferences of candidates and their overall understanding of the subject. This method is very useful in understanding behavioural responses of individuals. Shiva \& Singh (2019) studied the behavior of retail investors using this approach. In this study we are using this approach to understand job preferences and expectations of students in the current scenario of pandemic.

Literature indicates that conjoint analysis is an appropriate method for assessing consumer preferences (Green and Srinivasan, 1978; Louviere and Islam, 2008). It is an advanced exploratory technique which helps in determining the relative importance of various attributes on students' perception of different factors (in our study it means-salary, work hours, organizational reputation and job security)

In the present study, we studied literature extensively and came across several job attributes. We conducted a survey on 40 undergraduate students to refine the attributes and also organized focus group discussion by dividing the students into two groups. On the basis of the initial study, researchers continued with four major attributes for the study. Earlier researches have studied 10-15 attributes, but when too many choices are given to respondents, they might get either confused or fatigued. We used four job attributes and their levels. An orthogonal design was generated in SPSS 20.0.

The orthogonal design generated eight choice cards which was a combination of attributes. These cards were considered as a hypothetical job offer. A questionnaire was created using these card choices. Respondents were asked to rank the combination of attributes (hypothetical job offer) in order of their preference from 1-8, 1 being most preferred and 8 being least preferred. The questionnaire was provided to 170 final year students of communication at a University in north India. Convenience sampling was done and respondents were briefed about the appropriate way to complete the questionnaire. However, 20 responses were removed since all job combinations were not ranked and therefore could not be considered for the study. The sample was collected in August'20- September'20.

\section{Job Attributes}

Table 1: Attribute and levels in this research

\begin{tabular}{|c|c|c|}
\hline $\begin{array}{l}\text { S. } \\
\text { No }\end{array}$ & $\begin{array}{l}\text { Name of } \\
\text { Attribute }\end{array}$ & Levels Associated \\
\hline \multirow[t]{4}{*}{1} & \multirow[t]{4}{*}{ Salary } & $\begin{array}{l}\text { Less than INR } 3 \\
\text { lakhs }\end{array}$ \\
\hline & & INR 3-5 lakhs \\
\hline & & INR 5-7 Lakhs \\
\hline & & $\begin{array}{l}\text { More than INR } 7 \\
\text { lakhs }\end{array}$ \\
\hline \multirow[t]{2}{*}{2} & \multirow[t]{2}{*}{ Workhours } & Shift \\
\hline & & Normal \\
\hline \multirow[t]{2}{*}{3} & \multirow{2}{*}{$\begin{array}{l}\text { Organizational } \\
\text { Reputation }\end{array}$} & High \\
\hline & & Low \\
\hline \multirow[t]{2}{*}{4} & \multirow[t]{2}{*}{ Job Security } & High \\
\hline & & Low \\
\hline
\end{tabular}

Source: SPSS Orthogonal design; Source: Author's Calculations

We used four job attributes and their levels. An orthogonal design was generated in SPSS 20.0. The orthogonal design generated eight choice cards which was a combination of attributes. These cards were considered as a hypothetical job offer. A questionnaire was created using these cards choices. Respondents were asked to rank the combination of attributes (Hypothetical job offer) in order of their preference from 1-8. 1 being most preferred and 8 being least preferred. The questionnaire was provided to 170 final year students of communication at a University in north India. Convenience sampling was done and respondents were briefed about the appropriate way to complete the questionnaire. However, 20 responses were removed since all job combinations were not ranked, therefore could not be considered for the study. 
RESULTS

Estimated utilities

Table 2. Estimated utilities

\begin{tabular}{|c|c|c|c|}
\hline \multicolumn{4}{|l|}{ Utilities } \\
\hline & & $\begin{array}{l}\text { Utility } \\
\text { Estimate }\end{array}$ & $\begin{array}{l}\text { Std. } \\
\text { Error }\end{array}$ \\
\hline \multirow{4}{*}{ Salary in INR } & $<3$ Lakhs & 0.022 & 0.09 \\
\hline & 3-5 Lakhs & 0.043 & 0.18 \\
\hline & 5-7 lakhs & 0.065 & 0.27 \\
\hline & > 7 Lakhs & 0.087 & 0.359 \\
\hline \multirow{2}{*}{ Work Hours } & Normal & -0.882 & 0.201 \\
\hline & Shift & -1.763 & 0.402 \\
\hline \multirow{2}{*}{$\begin{array}{l}\text { Organization } \\
\text { al reputation }\end{array}$} & High & 0.336 & 0.201 \\
\hline & Low & 0.671 & 0.402 \\
\hline \multirow{2}{*}{ Job Security } & High & -1.477 & 0.201 \\
\hline & Low & -2.954 & 0.402 \\
\hline \multicolumn{2}{|l|}{ (Constant) } & 7.48 & 0.577 \\
\hline
\end{tabular}

Source: Author's Calculation

The conjoint analysis was conducted on SPSS.17 and we obtained preference values that respondents unknowingly assigned to each job attribute provided to them in the form of questionnaire. The utility estimates of each attribute and each level has been studied in this paper and are represented in Table 3. In this Table, negative values depict lesser preference for the attribute. In our study, for the job attribute of salary, we have highest utility value for the level- more 7 LPA i.e., 0.087 , and least utility value for the level -less that 3LPA i.e., .022. For the next attribute which is workhours, the utility value is higher for normal workhours- -0.882 - than working in shift which has a utility value of -1.763 . For Organization reputation, utility value for low level is higher (.671) than high level (.336), which means that students are not much concerned about reputation of the organization, though job security has the highest utility for high level (-1.477) than low($2.954)$, which implies that high job security is the important attribute for students.

Table 3: Importance Summary

Averaged Importance score

\begin{tabular}{|l|l|}
\hline Salary & 2.361 \\
\hline Work Hours & 31.95 \\
\hline Organizational Reputation & 12.16 \\
\hline Job Security & 53.529 \\
\hline
\end{tabular}

Source: Author's Calculation

\section{Relative Importance}

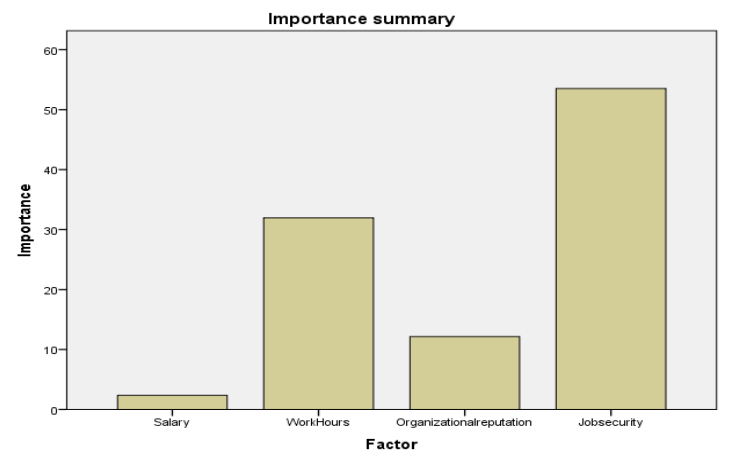

Source: Author's Calculations

Results for relative importance depict that job security is the most important attribute and plays a pivotal role in making job choice decisions; this attribute has the highest importance score of $54 \%$. The second highest importance score is for work hours which is $32 \%$; it implies that after job security, workhours is the next important attribute which students weigh more than other attributes such as organizational reputation $(12 \%)$ and salary is the least important $(2 \%)$. Results suggest a high level of significance, as indicated by Pearson's coefficient of 0.981 and p-value 0.000 . This represents a significant correlation between observed and estimated preferences (Wilcox, 2008).

\section{DISCUSSION AND THEORETICAL IMPLICATION}

The current economic scenario has taken a toll on students. With huge layoffs happening worldwide, there are lesser organizations going for campus selection. This study has been done on media and communication students who are budding journalists; they are worried about future jobs. Unlike studies done earlier, which stated that salary and benefits are the most preferred job attribute (Yasmin et al., 2016; Karima et al., 2020), and organizational reputation also being of significant importance to them (Montgomery \& Ramus, 2011), our study in the pandemic situation yields results that are different. Here, the most important job attribute for students is job security. While they are ready to compromise on salary and organizational reputation, in these uncertain times, they are keener on job security and work hours. There have been some researches before the pandemic also which have revealed that job security plays a key role in job choice decision (Hsiao and Nova ,2016). This is in alignment 
with conservation of resource theory, where an individuals' during difficult times try to maintain their resources or try to acquire new resources and loss of any resource may lead to stress or anxiety in individuals. This is in alignment with conservation of resource theory, where during difficult times, individuals try to maintain their resources or try to acquire new resources, and loss of any resource may lead to stress or anxiety. Although sometimes people showcase altruistic behaviour (Herzberg, 1966) and underrepresent their monetary needs, ongoing circumstances back the results. In the current situation when organizations are not hiring, having a job at hand is important for students rather than reputation of the organization. We can conclude from this study that pay packages are not always sufficient to attract a talent pool now; there are various other factors that affect job choice decision, and mostly their life situations play a key role in choice of job. Nowadays, everyone is going through pandemic times which was never seen or heard before. Not just the individual, but the world is not well equipped to handle this situation perfectly. This makes the road difficult for students to tread; they are scared for their future like never before. Pay package does not attract the potential talent pool anymore, but job security does. It not only reduces their stress but also may improve their commitment towards the organization.

\section{Managerial Implications}

This study is very useful for recruitment managers. Since the markets have been predicted to open for hiring post-January 2021, they need to consider students' job choice preferences and work on the job offer which must be a win-win for both. They need to make amendments in their policies in order to prove their credibility to a potential talent pool and can convince them of job security. Also, they need to come up with an appropriate work hour policy, since working in shifts for longer duration may take a toll on employees' mental health as well as hamper their worklife balance. Another issue that has come up in these difficult times is of work boundaries. Since people are working from home, work timings have lost importance, organizations expect them to be available all the time, odd shift timings make it more difficult and affects the psychological well-being of the individuals. Therefore, the culture of normal work hours should be encouraged.

\section{Limitations of the study and direction for future research}

This study was conducted on 152 students of a single university. In future studies, we can include more colleges from different geographies and larger number of students, to have a better sample and robust results. Here we have considered four major job attributes, but there are many other attributes that can be considered and studied upon, to get a clearer picture of students' preferences. Furthermore, lack of skill in respondents to appropriately rank the attribute preferences and respondent's fatigue can raise issues that may require further investigation. In future, this study can be conducted on top media colleges pan India, with inclusion of other job attributes as well, so as to get a broader view of job preferences.

\section{CONCLUSION}

Ralph Heibutzki (2013) suggested that job security is an important dimension for employees as it touches upon their basic career expectations such as: stability in career is equivalent to stability in life; it enhances motivation and confidence towards life situations; and, it provides stability to the curriculum vitae, therefore it makes good foundation for the next job. It is not just job aspiration, but every human aspires for stability in all the dimensions of life, job being one of them. Therefore, organizations should start designing compensation and benefits package, and also recruitment policies, that can provide assurance to prospective employees that they will stay in the job if they perform well. Hiring managers should take this opportunity to create a committed and loyal workforce that will stay with them for a longer term and help them achieve desired success, when the world revives from this pandemic.

\section{REFERENCES}

Achim, Nur`ain \& Badrolhisam, Nur \& Zulkipli, Nurfitriah. (2019). Employee career decision making: the influence of salary and benefits, work environment and job security. Journal of Academia, Vol. 7. 41-50. 
Ali, Raza \& Lynch, Richard \& Melewar, T. \& Jin, Zhongqi. (2014). The moderating influences on the relationship of corporate reputation with its antecedents and consequences: A meta-analytic review. Journal of Business Research. 10.1016/j.jbusres.2014.10.013.

Barney, J.B. and Wright, P.M. (1998). On Becoming a Strategic Partner: The Role of Human Resources in Gaining Competitive Advantage, Human Resource Management, 37: 31-46.

Belt, J. A., \& Paolillo, J. G. P. (1982). The influence of corporate image and specificity of candidate qualifications on response to recruitment advertisement. Journal of Management, 8, 105-112.

Borland, Jeff. (1999). Job security in Australia, Paper presented at Conference of Economists, Latrobe University.

Browne, B. A. (1997). Gender and preferences for job attributes: A cross cultural comparison. Sex Roles, 37(1-2), 61-71. Http:/ / dx.doi.org/10.1023/ A:102568860 3525

Chung, H., \& Van der Horst, M. (2018a). Flexible working and unpaid overtime in the UK: The role of gender, parental and occupational status. Social Indicators Research.

Chung, Heejung \& Lippe, T.. (2020). Flexible Working, Work-Life Balance, and Gender: Introduction. Soc Indic Res 151, 365-381 (2020)

Corrigall, E. A., \& Konrad, A. M. (2006). The relationship of job attribute preferences to employment, hours of paid work, and family responsibilities: An analysis comparing women and men. Sex Roles, 54(1-2), 95-111.

Debus, Maike \& Unger, Dana \& König, Cornelius. (2020). Job Insecurity and Performance over Time: The Critical Role of Job Insecurity Duration. Career Development International. 25. 325-336.

Deloitte. (2018). Deloitte millennial survey. Accessed October 24, 2018. Https://www2.deloitte.com/global /en/pages/aboutdeloitte/articles/millennialsurvey.html.
Demerouti, E., Bakker, A. B., \& Leiter, M. (2014). Burnout and job performance: The moderating role of selection, optimization, and compensation strategies. Journal of Occupational Health Psychology, 19(1), 96.

Dowling, Grahame. (2016). Defining and Measuring Corporate Reputations: Corporate Reputations. European Management Review. 13. 10.1111/emre.12081.

E. Michaels, H. Handfield-Jones and B. Axelrod. (2001). The War for Talent (Boston: Harvard Business School Press). Equality: Introduction. Social Indicators Research. 151. 1-17. 10.1007/s11205-0182025-x.

Aucejo , M.; Jacob F ;Araya M.P \& Zafar . B (2020). "The Impact of COVID-19 on Student Experiences and Expectations: Evidence from a Survey," NBER Working Papers 27392, National Bureau of Economic Research, Inc.

Ferreira, D., \& Baidya, T. K. (2016). The Impact Of Compensation Systems On The Motivation Of Teachers Of A Higher Education Institution. International Journal Of Business Management and Economic Research (IJBMER), 7(6), 793-803.

Fombrun, C., \& Shanley, M. (1990). What's in a name? Reputation building and corporate strategy. Academy of Management Journal, 33(2), 233-258.

Grantham, C., Ware, J., \& Swanberg, J. (2009), Flexible Work Arrangements for Nonexempt Employees. Retrieved From http:/ / www.worldatwork.org/waw/adi mLink?id=33622

Green, P.E. and Rao, V.R. (1971). Conjoint measurement for quantifying judgmental data, Journal of Marketing Research, Vol. 3, pp. 355-363.

Green, P.E. and Srinivasan, V. (1978). Conjoint analysis in consumer research: Issues and outlook, Journal of Consumer Research, Vol. 5 No. 2, pp. $103-123$.

Green, P.E. and Srinivasan, V. (1990). Conjoint analysis in marketing: new developments with implications for research and practice, Journal of Marketing, Vol. 4, pp. 3-19. 
Green, P.E., Krieger, A.M. and Wind, Y. (2001). Thirty Years of Conjoint Analysis: Reflections and Prospects. Interfaces, 31, 56-73.

http://dx.doi.org/10.1287/inte.31.3s.56.9 676

Guillot-Soulez, Chloé \& Soulez, Sébastien. (2014). On the heterogeneity of Generation Y job preferences. Employee Relations. 36. 10.1108/ER-07-2013-0073.]

Havryley.Y; Rizun.V \& Shenderovskyj.K.(2019). Impact of TV News on Psycho-Physiological State Depending on Emotional Burnout, Journal of Content, Community $\mathcal{E}$ Communication, 5 (9), 13-25, 2019

Herzberg, F. (1966). Motivate Employees? World, 88.

Hsiao, J. \& Nova, Silvia P. (2016). Generational Approach to Factors Influencing Career Choice in Accounting, Revista Contabilidade \& Finanças, 27(72): 393-407

Jandaghi, G., Mokhles, A. \& Bahrami, H. (2011). The Impact of Job Security on Employees' Commitment and Job Satisfaction in Qom Municipalities, African Journal of Business Management, 5(16), 6853-6858.

Jehn, K. A., \& Scott, E. D. (2015). Lies in the Sky: Effects of Employee Dishonesty on Organizational Reputation in the Airline Industry. Business and Society Review, 120(1), 115-136.

Karima, R \& Setiadi, Rianti \& Siswantining, Titin. (2020). Preference analysis of determining jobs using conjoint analysis. Journal of Physics: Conference Series. 1442. 012040.

$10.1088 / 1742-$ 6596/1442/1/012040.

Kelly, E. L., Moen, P., \& Tranby, E. (2011). Changing workplaces to reduce workfamily conflict schedule control in a white-collar organization. American Sociological Review, 76(2), 265-290.

Kelly, E. L., Moen, P., Oakes, J. M., Fan, W., Okechukwu, C., Davis, K. D. et al. (2014). Changing work and work-family conflict: Evidence from the work, family, and health network. American Sociological Review, 79(3),

485-
516. Https://doi.org/10.1177/000312241 4531435 .

Konrad, A. M. (2003). Family demands and job attribute preferences: A 4-year longitudinal study of women and men. Sex Roles, 49(1-2), 35-46.

Konrad, A. M., Ritchie Jr, J. E., Lieb, P., \& Corrigall, E. (2000). Sex differences and similarities in job attribute preferences: a meta-analysis. Psychological Bulletin, 126(4), 593-641. Http:/ / dx.doi.org/10.1037/0033-2909. 126.4.593

Kramer, A., \& Kramer, K. Z. (2020). The potential impact of the Covid-19 pandemic on occupational status, work from home, and occupational mobility. Journal of vocational behavior, 119, 103442.

Llanos, L. F., \& Ahmad, R. (2017). Financial Compensation and Organizational Commitment: Differences Among Mexican and Malaysian Bankers. Compensation \& Benefits Review, 1-16

Locke, E. A., Feren, D. B., mccaleb, V. M., Shaw, K. N., \& Denny, A. T. (1980). The relative effectiveness of four methods of motivating employee performance. In K. D. Duncan, M. M. Gruneberg, \& D. Wallis (Eds.), Changes in Working Life (pp. 363-388). London: Wiley.

Lucky, E.O., Minai, M.S. \& Rahman, H. (2013). Impact of Job Security on the Organizational Performance in a Multiethnic Environment, Research Journal of Business Management, 7(1), 6470.

Meier, J., Austin, S. F., \& Crocker, M. (2010). Generation $Y$ in the workforce: Managerial challenges. The Journal of Human Resource and Adult Learning, 6(1), 68-78.

Montgomery,D.S, Ramus.C.A (2011). Calibrating MBA Job Preferences for the 21st Century. Academy of Management Learning $\mathcal{E}$ Education

$\mathrm{Ng}$, Eddy \& Schweitzer, Linda \& Lyons, Sean. (2010). New Generation, Great Expectations: A Field Study of the Millennial Generation. Journal of Business 
and Psychology. 25. 281-292. 10.1007/s10869-010-9159-4.

Perrin T. (2003). Working Today: Understanding What Drives Employee Engagement The 2003 Towers Perrin Talent Report U.S Report. [Online] Available:

http://www.towersperrin.com/tp/getw ebcachedoc? Webc = HRS /USA/2003/200309/Talent_2003.pdf (October 30, 2008)

Pinder, C. C. (1998). Motivation in Work Organizations. Upper Saddle River, NJ.

Rocereto, J., Gupta, S., \& Mosca, J.(2011). The Role of Flextime Appeal on Family and Work Outcomes Among Active and Nonactive Flextime Users: A Between Groups and Within Groups Analysis. Journal of Business E Economics Research, 9,(3),pp 5766.

Rynes, Sara \& Barber, Alison. (1990). Applicant Attraction Strategies: An Organizational Perspective. CAHRS Working Paper Series. 15. 10.5465/AMR.1990.4308158.

Sanyal, Shouvik \& Hisam, Mohammed \& BaOmar, Zainab. (2018). Loss Of Job Security And Its Impact On Employee Performance - A Study In Sultanate Of Oman. International Journal of Innovative Research and Growth. 7. 10.26671/IJIRG.2018.6.7.101.

Shiva, A. And Singh, M. (2019). Stock hunting or blue-chip investments? Investors' preferences for stocks in virtual geographies of social networks, Qualitative Research in Financial Markets, Vol. 12 No. 1, pp. 123. Https://doi.org/10.1108/QRFM-112018-0120

Smola, Karen \& Sutton, Charlotte. (2002). Generational Differences: Revisiting Generational Work Values for the New Millennium. Journal of Organizational Behavior. 23. 363 - 382. 10.1002/job.147.
Sutherland, J. (2011). Job attribute preferences: who prefers what? Employee Relations, 34(2), 193-221. Http:/ /dx.doi.org/10.1108/01425451211 191896

Ten Brummelhuis, L. L., \& Van der Lippe, T. (2010). Effective work-life balance support for various household structures. Human Resource Management, 49(2), 173-193.

Tolbert, P. S., \& Moen, P. (1998). Men's and Women's Definitions of "Good" Jobs Similarities and Differences by Age and Across Time. Work and Occupations, 25(2), 168-194.

Tran, H. (2016). The impact of pay satisfaction and school achievement on high school principals' turnover intentions. Educational Management Administration $\mathcal{E}$ Leadership,

1-18. https://doi.org/10.1177/17411432166361 15

Wilcox, R. T. (2008). A practical guide to conjoint analysis. Darden Case No.UVAM-0675. Retrieved from http:/ / ssrn.com/abstract $=1280602$

Yamoah, E. E. (2013). Relationship Between Compensation and Employee Productivity. Singaporean Journal of Business Economics and Management Studies, 2(1), 110-114. https://doi.org/10.12816/0003845

Yasmin.S.,Mahmud.,K.Afrin (2016). Job Attribute Preference of Executives: A Conjoint Analysis, Asian Social Science; Vol. 12, No. 2; 2016

Zavyalova, A., Pfarrer, M. D., Reger, R. K., \& Hubbard, T. D. (2016). Reputation as a benefit and a burden? How stakeholders' organizational identification affects the role of reputation following a negative event. Academy of Management Journal, 59(1), 253-276. 